\title{
Popular Classes, Revolution and Labour Relations in Nineteenth-Century Argentina
}

\author{
Gabriel DiMeglio
}

After the Napoleonic invasion of Spain in 1808, several revolutions erupted in Hispanic America. They involved a fight to achieve self-government, and eventually led to the independence of several republics of the former Spanish Empire. These revolutions were led by sections of the local elites, but in many of them the popular classes - urban plebeians, artisans, slaves, peasants and other rural labourers - also played a key role. This chapter focuses on their actions during the revolutionary process in the territories that would later become one of the new countries born as a result: Argentina. ${ }^{1}$

The revolutionary period has always been a central topic in Argentine historiography. Since the 1970s, traditional narratives about a struggle between proto-nationalist Criollos (American-born Spaniards) and the Spanish monarchy have been challenged by revisionist readings in the fields of political, cultural, conceptual, economic and social history. ${ }^{2}$ Nowadays, researchers argue that it is impossible to study Spanish American independence through a retrospective view of the present national borders. ${ }^{3}$ Instead, the emergence of Argentina as an independent nation can only be understood in connection with the

1 At the beginning of the nineteenth century, a large proportion of present-day Argentine territories were part of the Viceroyalty of the Río de la Plata, while other areas were not included in the Spanish jurisdiction and were controlled by indigenous sovereign groups. The destruction of the Viceroyalty in the 1820 os led to the making of four different countries: Argentina, Uruguay, Paraguay and Bolivia.

2 The revision started with Tulio Halperin Donghi, Politics, Economics and Society in Argentina in the Revolutionary Period, (New York: Cambridge University Press, 1975), first published in Spanish in 1972. The vast body of literature on the political history of the revolutionary period since then is too large to be described here. For a complete review, see Noemí Goldman and Fabio Wasserman "Un balance de la historia política y de la construcción de identidades en el proceso de independencia”, Investigaciones y Ensayos 62 (2016): 23-46.

3 Especially after the work of José Carlos Chiaramonte. See mainly his Ciudades, provincias, Estados: Orígenes de la Nación Argentina (1800-1846) (Buenos Aires: Editora Espasa Calpe Argentina, 1998) and Fundamentos intelectuales y políticos de las independencias. Notas para una nueva historia intelectual de Iberoamérica (Buenos Aires: Teseo, 2010). 
broader Spanish Empire. ${ }^{4}$ Historians also show that when the revolution started in 1810, independence was not planned or even desired except by a very few. Instead, most revolutionaries wanted to secure self-government within a new federal Spanish monarchy. ${ }^{5}$ It is now clear that prior to the revolution, no Argentine national identity existed. Instead, this was slowly constructed in the following decades. ${ }^{6}$ Researchers have demonstrated that the revolution was not only carried out by a small group of wealthy white men, but also by many other crucial actors. This changing historiography has thus highlighted the importance of popular classes with regard to the revolution, and has examined how social and racial tensions were politicized during this period. ${ }^{7}$

Students of workers and labour relations had their own separate agendas, which only occasionally overlapped with studies of the revolution. From the 1940s to the 1970s, a variety of Marxist intellectuals in Argentina - as in many Latin American countries - debated whether the productive structure of colonial America had been feudal or capitalist. In this discussion, the two systems were thought of as rigidly separated. The diversity and mobility of workers in the continent seemed far removed from the European feudal model of masters exerting coercion to obtain a surplus from the landed peasantry. In most cases,

4 Tulio Halperin Donghi, Reforma y Disolución de los Imperios Ibéricos, 1750-1850, (Madrid: Alianza editorial, 1985); François-Xavier Guerra, Modernidad e independencias: Ensayos sobre las revoluciones hispánicas (Madrid: Ediciones Encuentro, 1992). Guerra's book was very influential all around Latin America.

5 José María Portillo Valdés, Crisis Atlántica. Autonomía e independencia en la crisis de la monarquía hispana (Madrid: Marcial Pons Ediciones de Historia, 20o6); Noemí Goldman, "Buenos Aires, 1810: la 'revolución', el dilema de la legitimidad y de las representaciones de la soberanía del pueblo", Historia y política: Ideas, procesos y movimientos sociales 24 (2010): $47-69$.

6 José Carlos Chiaramonte, "Formas de identidad en el Río de la Plata luego de 1810", Boletín del Instituto de Historia Argentina y Americana "Dr. Emilio Ravignani" no. 1 (1989): 71-92. His perspective was discussed by Pilar González Bernaldo, "La 'identidad nacional' en el Río de la Plata postcolonial: Continuidades y rupturas con el Antiguo Régimen”, Anuario IEHS 12 (1997): 109-122, and also Jorge Myers, "Una cuestión de identidades: La búsqueda de los orígenes de la Nación Argentina y sus aporías", Prismas 3 (1999): 275-284.

7 Gabriel Di Meglio, ¡Viva el bajo pueblo! La plebe urbana de Buenos Aires y la política entre la Revolución de Mayo y el rosismo (Buenos Aires: Prometeo Libros, 20o6); Ana Frega, Pueblos y soberanía en la revolución artiguista: La región de Santo Domingo Soriano desde fines de la colonia hasta la ocupación portuguesa (Montevideo: Ediciones de la Banda Oriental, 2007); Sara Mata, Los gauchos de Güemes: Guerras de independencia y conflicto social (Buenos Aires: Sudamericana, 2008); Raúl Fradkin, ¿Y el pueblo dónde está? Contribuciones para una historia popular de la Revolución de independencia en el Río de la Plata (Buenos Aires: Prometeo Libros, 2008); Raúl Fradkin, "La revolución en los pueblos del litoral rioplatense", Estudios Ibero-Americanos 36, no. 2 (2010): 242-265. 
indebtedness had been ineffective to tie the workforce to a property in colonial Hispanic America. Moreover, in the area covered in this chapter, instead of trying to tie the peasantry to their land, many landowners pressured the state to evict occupiers, and coercion was mostly exercised by state authorities rather than by landowners. However, while clearly not feudal, colonial society was not classically capitalist either. For a long time, most people were not forced to sell their labour power on the market in order to subsist. Undoubtedly there were wage workers, but in most places they had alternatives to the market to make a living. Apart from wage labourers, there were also many slaves, an extensive and heterogeneous independent peasantry, and a large group of small business owners, such as artisans. Some historians have therefore proposed an alternative definition of capitalism as a profit-driven system that produced commodities for large markets, and which could contain diverse relations of production. This definition was rejected by those who took proletarianization to be capitalism's central feature and who emphasized that Latin America had a specific economic and social organization. The revolution of the 1810 s was not central to this debate, as many scholars considered that it had not changed the mode of production. Some Marxists did think of the revolution as a challenge to the social structure, but as a failed one: in the end, labour relations remained the same. ${ }^{8}$

The debate had not been settled, but it was more or less abandoned after the 1980s. The number of studies into labour relations grew remarkably, but without engaging in a debate about the modes of production. Some scholars studied general aspects of the development of "agrarian capitalism" through the nineteenth century, ${ }^{9}$ some looked for its origins, either in the late colonial

8 A clear synthesis of the arguments is found in Steve Stern, "Feudalism, Capitalism, and the World-System in the Perspective of Latin America and the Caribbean", AHR 93, no. 4 (1988): 829-872. With regard to the history of the debate, see José Carlos Chiaramonte, Formas de sociedad y economía en Hispanoamérica (Buenos Aires: Grijalbo, 1984). The proposal of capitalism as a profit-driven system is in Andre Gunder Frank, Capitalism and Underdevelopment in Latin America: Historical Studies of Chile and Brazil (New York: Monthly Review Press, 1967), and the main critics of it (by Ernesto Laclau and Carlos Assadourian) in Carlos Sempat Assadourian, et al., Modos de producción en América Latina (México: Pasado y Presente, 1973). It was Rodolfo Puiggrós who talked about a failed democratic-bourgeois revolution, in Rodolfo Puiggrós, De la colonia a la revolución (Buenos Aires: Retórica, 1940).

9 For example Osvaldo Barsky and Julio Djenderedjian, Historia del capitalismo agrario pampeano: La expansión ganadera hasta 1895 (Buenos Aires: Universidad de Belgrano, 2003). A recent review of this strand of research can be found in Eduardo Míguez, "Del feudalismo al capitalismo agrario: ¿el fin de la historia ... agraria?" Boletín del Instituto de Historia Argentina y Americana "Dr. Emilio Ravignani" 46 (2017): 180-204. The current debates about Capitalism, the "Global South" and "Slavery Capitalism" have not yet influenced the Argentine historiography of the early nineteenth century. 
period or in the mid-1850s, ${ }^{10}$ while others focused on the process of proletarianization, which they considered had become prevalent in the late nineteenth century. ${ }^{11}$ In all these lines of research, the revolution was considered a major break, because it was followed by a re-orientation of the economy of the region. Yet few scholars have attempted to connect popular actions during the revolution with the transformations in the world of labour.

That is precisely the goal of this chapter. By creating a "conversation" between the historiographies of revolution and of labour in Argentina, I aim to analyse how labour relations were affected by the political actions of the popular classes. $^{12}$

\section{Labour Relations at the Beginning of the Nineteenth Century}

The chapter explores the relationship between revolution and labour in a region of what was the Viceroyalty of the Rio de la Plata: the Pampas; a broad and fertile plain that included the present-day Argentine provinces of Buenos Aires, Entre Ríos, Santa Fe and also the Banda Oriental. The last of these is now another country: Uruguay. ${ }^{13}$ The focus here is mostly on Buenos Aires, which

10 Respectively Samuel Amaral, The Rise of capitalism on the Pampas: The Estancias of Buenos Aires, 1785-1870 (Cambridge: Cambridge University Press, 1998); Hilda Sabato, Capitalismo y ganadería en Buenos Aires: la fiebre del lanar (Buenos Aires: Editorial Sudamericana, 1989).

11 For example Ricardo Salvatore, "Reclutamiento militar, disciplinamiento y proletarización en la era de Rosas", Boletín del Instituto de Historia Argentina y Americana "Dr. Emilio Ravignnani" 5 (1992): 25-47; Juan Carlos Garavaglia, "De Caseros a la guerra del Paraguay: el disciplinamiento de la población campesina en el Buenos Aires postrosista (1852-1865)", Illes i Imperis, no. 5 (2001): 53-80; Daniel Campi, "Trabajo, azúcar, disciplinamiento y resistencia: El caso de Tucumán, Argentina (segunda mitad del siglo XIX)", in Historia do Açúcar: Fiscalidade, metrologia, vida material e patrimonio, ed. Alberto Viera et al. (Funchal: CeHa, 2006).

12 Naturally, I have included texts about Argentina written in other countries, and I also take from Uruguayan historiography. The chapter is based on a secondary bibliography, although a few primary sources are used to provide examples. I have translated all the citations from Spanish into English.

13 Roughly speaking, the area was geographically and historically different from the rest of what today is Argentina, the "interior" provinces more closely resembling of other Andean regions. There were also huge plains in which different indigenous groups resisted the Spanish conquest and kept their sovereignty, their languages and their religion until the last quarter of the nineteenth century: Chaco in the North and Patagonia in the South. There is a vast bibliography on the indigenous groups of both regions. For a general summary, see Raúl Mandrini, La Argentina aborigen (Buenos Aires: Siglo xxı Editores, 2008). 
in the 181os experienced a significant popular mobilization in support of the struggle against the colonial authorities. The mobilization was more urban than rural. Labour relations were not at the heart of the political disputes of that agitated period, but they were affected by the consequences of the revolutionary process. On the other hand, the uprising in the Banda Oriental and Entre Ríos was mainly rural, and openly took issue with many aspects of the agrarian relations. Some of these disputes concerned pre-existing conditions. In order to make sense of this, the current section provides a brief overview of labour relations in the area in colonial times.

In this vast and scarcely-populated plain, most people lived in the countryside and worked in rural activities. They produced wheat and fruit for the urban markets and hides for export, and raised mules to be sent to the distant mines of Potosí. Many rural workers were peasants, who worked small and medium-sized plots and were generally engaged in a combination of agriculture and livestock breeding. A few of them owned their land, but most were settled on others' properties. Many were tenants, who paid their rent in various ways: in money, in wheat or in animals. Others were sharecroppers. There were also the so-called "aggregates", who exchanged work for land, but in contrast to the tenants, lived in the same residence as the owner or another tenant, or next to it. In addition, there was still another alternative for members of the popular classes to access the land: to occupy it without permission from the owners. Land was not fenced, and large "empty" spaces that were not used for production existed all around. The repressive capacity of the state was low, and many landowners had little control of their holdings, some of which were not actually occupied by them. They often complained about intruders, but sometimes ended up negotiating some form of collaboration with the occupants, such as demanding their help to control herds or employing them as casual labourers. ${ }^{14}$

The other main form of rural labour was related to the haciendas or estancias: large landholdings dedicated to producing cattle, mules and sometimes crops. Many haciendas had tenants who paid part of their rent in the

14 There is a vast bibliography on this topic. Three indispensable books are Jorge Gelman, Campesinos y estancieros: Una región del Rio de la Plata a fines de la época colonial (Buenos Aires: Editorial Los Libros del Riel, 1998); Juan Carlos Garavaglia, Pastores y labradores de Buenos Aires: una historia agraria de la campaña bonaerense 1700-1830 (Buenos Aires: Ediciones de la Flor, 1999); Carlos Mayo, Estancia y sociedad en la Pampa (1740-1820) (Buenos Aires: Biblos, 2010). Also see José Mateo, Población, parentesco y red social en la frontera. Lobos (provincia de Buenos Aires) en el siglo XIX (Mar del Plata: Universidad Nacional de Mar del Plata, 20o1). 
form of labour. Further, given the shortage of workers and the irregularity of demand for labour in cattle raising - which was concentrated in short periods each year devoted to livestock branding and slaughtering - the hacendados employed temporary labourers for those months and kept a group of slaves in charge of the permanent tasks. These slaves were the only people working at the hacienda for the entire year, and because of that some of them were even able to become bosses of free labourers, ${ }^{15}$ who were hired in high season, both per month and per day (journeymen). They were paid in currency and in kind, and while they were working they were given lodging and food. Wages in the Pampas were significantly higher than in other parts of the Viceroyalty. However, though the area attracted many migrants - seasonally or permanently in-migration was not great enough to supply all the labour required by the haciendas. Many workers would leave one hacienda for another if they disagreed with the bosses or were paid after the due date, which was common. Labour mobility was high. ${ }^{16}$

Most of the labourers were not fully dependent on wages alone. Subsistence alternatives continued to exist, such as hunting wild animals, including otters, rodents and rheas, fishing or killing someone else's cow. Many entered and left the market, and therefore were not necessarily full-time labourers. At the same time, patterns of employment changed over a lifetime. Men from other regions went to the Pampas to get money, and then returned to their homes, where they became peasants again. Others remained in a proletarian position or lived on the margins of society. In the eighteenth century, the latter were called gauchos, but as decades went by, that word started to be used to denominate every poor man in the countryside. Another option for labourers was to form a family, obtain some seeds and tools or some cows, and start a small herd. Thus, they could become peasants; a route that was made possible because land was quite easy to obtain. ${ }^{17}$

15 Carlos Mayo, "Patricio Belén: nada menos que un capataz", Hispanic American Historical Review 77, no. 4 (1997): 597-617.

16 Mariana Canedo, Propietarios, ocupantes y pobladores: San Nicolás de los Arroyos, $1600-$ 1860 (Mar del Plata: Universidad Nacional de Mar del Plata, 200o). See also Roy Hora, Historia económica de la Argentina en el siglo XIX (Buenos Aires: Siglo Xxi/Fundación OSDE, 2010).

17 An early and useful synthesis of these topics in English is Juan Carlos Garavaglia and Jorge Gelman, "Rural History of the Rio de la Plata, 160o-1850: results of a historiographical renaissance", Latin American Research Review 30, no. 3 (1995): 75-105. A recent balance can be found in Jorge Gelman, "De la historia agraria a la historia de las desigualdades. Un recorrido y varios homenajes", Anuario IEHS 32, no. 2 (2017): 47-58. See also Míguez, "Del feudalismo al capitalismo agrario" and the comments on the text in the same issue by Juan Manuel Palacio and Eduardo Barsky. 
Another fundamental aspect of rural life was the importance of customary notions that sanctioned access to resources. People from the popular classes considered that stones or firewood could be taken from others' land because they were scarce goods; that they could take their own livestock to graze in any surrounding field; that wild animals could be hunted for food; and that killing a cow was acceptable if it was done to meet a need. Custom established that a person who lived for a long time in a given place had the right to stay there. From the late eighteenth century onwards, the authorities and the major landowners tried unsuccessfully to stop these practices. Attempts to secure rights over their possessions were made in various places around the end of that century, generating tensions and disputes. ${ }^{18}$

Thus, the scarcity of population, and the availability of land and of food alternatives without becoming fully dependent on the market allowed the popular classes to negotiate their social position and working condition (in Buenos Aires there was also the possibility of crossing the frontier and joining independent indigenous groups). These factors also partly curbed the pressures from the elites, who always complained about workers "abandoning" their tasks after receiving a salary advance; one of the practices used to retain them and stop their mobility. Laws against "vagrants" were introduced during the eighteenth century, sending any man without a steady job into the army, but the goal was not easy to achieve. Even if coercion was occasionally able to make workers stay in a given place, it failed to generate a steady flow of labour to the market. Migrants were the ones who suffered most from the pressure of the authorities, because they had no local connections to defend themselves. ${ }^{19}$

There was one region in which rural relations were more tense before the revolution: the Banda Oriental and part of Entre Ríos. In the late eighteenth century, some rich people from Buenos Aires and Montevideo began obtaining land grants for cattle raising in the Banda Oriental, an area with a lower population because it had been colonized much later than Buenos Aires. The new owners started to clash with the untitled occupants who were already there, and who the owners tried to expel from their lands. These attempts were

18 Raúl Fradkin, "Entre la ley y la práctica: la costumbre en la campaña bonaerense de la primera mitad del siglo XIX", Anuario IE HS 12 (1997): 141-156.

19 María Elena Barral, Raúl Fradkin, Gladys Perri and Fabián Alonso, "Los vagos de la campaña bonaerense: la construcción histórica de una figura delictiva (1780-1830)", in El poder y la vara. Estudios sobre la justicia y la construcción del Estado en el Buenos Aires rural, comp. Raúl Fradkin (Buenos Aires: Prometeo Libros Editorial, 2007). Another perspective appears in Gabriela Martínez Dougnac, "Justicia colonial, orden social y peonaje obligatorio", in Poder Terrateniente, relaciones de producción y orden colonial, ed. Azcuy Ameghino (Buenos Aires: F. García Cambeiro, 1996), 185-225. 
sometimes resisted judicially by appealing to custom, but at other times they had a drastic ending: evictions and the destruction of homes. At the same time, the new landowners tended to control the best sources of water and to take for themselves the cattle that went to drink there. These situations and the lack of an adequate demarcation of the farms led to the tense situation in the region that arose during the revolutionary years. ${ }^{20}$

The cities in the area were small, except for Buenos Aires, which had more than 60,00o inhabitants by 1810, a significant number by South American standards of that time. ${ }^{21}$ Artisans dominated the urban workforce. At the beginning of the nineteenth century, about 6o per cent of craft activities in Buenos Aires were performed by Afro-descendants, who were the clear majority among the shoemakers and tailors. For a free black, being a craftsman offered the possibility of social advancement. Racial disputes arose among artisans, however. In the 179os, some black and mulatto shoemakers tried to separate themselves from the recently formed Guild of Shoemakers and create a different one. They even sent a petition to the king. In the debates and mobilizations around contesting the framework of guilds, they acquired some political experience.

$20 \quad$ José Pedro Barrán y Benjamín Nahum, Bases económicas de la revolución artiguista (Montevideo:Ediciones dela Banda Oriental, 2007); Lucía Sala deTouron, Nelson delaTorre and Julio Rodríguez, Estructura económico-social de la colonia (Montevideo: Ediciones Pueblos Unidos, 1967). Outside the area considered in this chapter, in various parts of what is present-day North-West Argentina, several indigenous communities worked their lands collectively and the chief then used that production to pay the tribute to the Crown. The mines of Potosí, in present-day Bolivia, had a special labour system: the mita, indigenous mandatory service that several communities had to cover every year. In what today is North-East Argentina, then the area of the former Jesuit missions - the Order had been ousted from the Spanish territories in 1767 - the Guaraní indigenous groups continued producing yerba mate and hides in communal lands as they had done before with the priests, but under the supervision of a secular administrator. See Julia Sarreal, The Guarani and Their Missions: A Socioeconomic History (Stanford: Stanford University Press, 2014). With regard to the indigenous villages, see a synthesis in Gabriela Sica, "Las sociedades indígenas del Tucumán colonial: una breve historia en larga duración. Siglos XVI a XIX", in La historia nacional en perspectiva regional. Nuevas investigaciones para viejos problemas, ed. Susana Bandieri and Sandra Fernández (Buenos Aires: Teseo, 2017), 41-82. For the mita, see Enrique Tandeter, Coacción y mercado. La minería de la plata en el Potosí Colonial, 1692-1826 (Buenos Aires: Siglo Xxi Editores, 1992). For examples of labour relations in other parts of present-day Argentina see Guillermo Madrazo, Hacienda y encomienda en los Andes. La puna argentina bajo el marquesado de Tojo. Siglos XVII a XIX (Buenos Aires: Fondo Editorial, 1982); Sara Mata, "Estructura agraria, la propiedad de la tierra en el Valle de Lerma, Valle Calchaquí y la Frontera Este (1750-180o)", Andes. Antropología e Historia, no. 1 (1990): 47-88.

21 According to new calculations made by Lyman Johnson, Workshop of Revolution: Plebeian Buenos Aires and the Atlantic World, 1776-1810 (Durham: Duke University Press, 2011). 
Many of the artisans were slaves, since it was often cheaper for masters to teach the craft to someone who could not leave. Other slaves learned a craft and exercised it independently, giving what they earned to their owners, who were not necessarily artisans. ${ }^{22}$ Slavery was crucial in the cities. In Buenos Aires, slaves accounted for more than 25 per cent of the population by 1810 . The women were seamstresses, ironers, washerwomen or wet nurses, and could even be forced by their masters to engage in prostitution. Brickyards, construction sites and bakeries - important not only for the local market but also for the crews of the ships docked in the port - used slave labour. Of course, a large number of slaves were also engaged in domestic activities. ${ }^{23}$

Apart from the slaves, Buenos Aires, Montevideo and smaller cities had a heterogeneous plebeian population. This included street vendors, wage workers, sailors, and in the ports, personnel responsible for maintaining the ships that arrived after the long transatlantic voyage. There were many people who did not have a fixed occupation and took employment in what they could find daily or periodically, from obtaining some goods and exchanging them for other things, to digging wells or tying firewood. They could also be beggars. ${ }^{24}$

All these people were massively mobilized by the British army's occupation of Buenos Aires in July 1806, and the subsequent reconquest of the city, aided by troops sent from Montevideo. Soon after the British defeat, a crowd pressed the city council (Cabildo) to forbid the return of Viceroy Sobremonte to the capital, which he had left when the invaders attacked. At the same time, a voluntary militia was organized, including most male adults in the city and its outskirts. Militiamen were inhabitants who were armed for the defence of the city. They were not regular soldiers, but were paid when on active service. Thus, the militia became a steady job for many plebeians. ${ }^{25}$ Officers were voted in by the soldiers, and the new organization became a channel of contact

22 Johnson, Workshop of Revolution; Miguel Ángel Rosal, Africanos y afrodescendientes en el Río de la Plata. Siglos XVII-XIX (Buenos Aires: 2009).

23 Alex Borucki, From Shipmates to Soldiers. Emerging Black Identities in the Río de la Plata, (Albuquerque: University of New Mexico Press, 2015); Juan Carlos Garavaglia, "El pan de cada día: el mercado del trigo en Buenos Aires, 1700-1820", Boletín del Instituto de Historia Argentina y Americana, "Dr. Emilio Ravignani" no. 4, (1991): 7-29; Marta Goldberg y Silvia Mallo, "La población africana en Buenos Aires y su campaña. Formas de vida y subsistencia, 1750-1850", Temas de Asia y África, no. 2 (1994): 15-69; Rosal, Africanos y afrodescendientes.

24 César García Belsunce, Buenos Aires. Su gente. 1800-1830, 3 Vols. (Buenos Aires: Emecé Distribuidora, 1976).

25 Tulio Halperin Donghi, "Revolutionary Militarization in Buenos Aires, 1806-1815", Past \& Present 40, no.1 (1968): 84-107. 
between the local elite and the plebeians, not mediated by the imperial order. The new units subsequently played a key role, intervening in local disputes in the midst of the Spanish imperial crisis. ${ }^{26}$

The revolution that was soon to start in the Viceroyalty of the Rio de la Plata was not the result of inner tensions, but a consequence of the collapse of the centre of the monarchy under the French offensive. However, when the process began, many local grievances became political, and that would also affect labour relations.

\section{2}

\section{Revolution}

In May 1810, the arrival in Buenos Aires of news about the fall of Spain at Bonaparte's hands led to the organization of a movement that removed the viceroy from power and created a junta to replace his position. This was a collective local government, similar to those created in several Spanish cities on behalf of the captive Ferdinand VII, and was initially supposed to rule until the return of the legitimate king. However, the junta wanted more than that. The aspiration for self-government was strong among the elites in Spanish America. They wanted to maintain their resources and elect their own authorities, cutting off the dependence on Spain, even though their desire was to remain within the monarchy. ${ }^{27}$ Many cities of the viceroyalty accepted the new government of Buenos Aires, while a few others did not, and declared their loyalty to a new and fragile regency council in Spain. Among them was Montevideo, in the Banda Oriental. The junta sent troops against the loyalists, starting a civil war that would eventually turn into a war of independence lasting for 15 years.

From the beginning, the junta tried to ensure the adhesion of the plebeians to the revolution in Buenos Aires. The support of militia officers and a large proportion of the secular clergy was especially useful. Mariano Moreno, the secretary of the junta, started to publish a journal and forced the priests to read it aloud before mass, addressing the illiterates. The government and the

26 Pilar González Bernaldo, "Producción de una nueva legitimidad: ejército y sociedades patrióticas en Buenos Aires entre 1810 y 1813", in AAVv, Imagen y recepción de la Revolución Francesa en la Argentina (1990): 27-51; Johnson, Workshop of Revolution.

27 Similar movements occurred in Caracas, Cartagena, Bogotá, Santiago de Chile and Quito. For Buenos Aires, see Noemí Goldman, "Buenos Aires, 1810". For the general process in Halperin Donghi, Reforma y disolución de los imperios ibéricos, and for Portillo Valdés, Crisis Atlántica. 
city council decided to organize public celebrations whenever good news for the cause arrived, which would lead in May 1811 to the creation of the most important festive occasion of that time: the anniversary of the revolution. These meetings had a massive attendance. ${ }^{28}$

Although at the beginning the leaders of the revolution promoted the controlled participation of common people, the politicization of the plebeians increased when a factional struggle broke out within the junta towards the end of 1810. While the moderate faction - gathered around the figure of President Cornelio Saavedra - had the aim of achieving self-government while remaining within the monarchy, the radicals - followers of Mariano Moreno - sought total independence and wanted to change many hierarchical aspects of society. ${ }^{29}$ To settle the conflict, the moderates counted on the support of most of the military units, but if the military units acted alone, they could have been accused of forcing a change through violence. Therefore, they found another solution: on the night of April 5, 1811, they organized a massive mobilization to displace their rivals from the junta. One of the radicals later wrote that the moderates went "from the city to the suburbs in search of machines to execute the movement, or, as it was said then, they appealed to the men of poncho and chiripá [plebeian garments] to confront the men of cloak and frock coat". ${ }^{30}$ Around fifteen hundred people, most of them plebeians, attended the demonstration. The troops showed up too, but remained as silent support. The mobilization was coordinated by the petty authorities of the urban quarters, appointed by the city council. ${ }^{31}$ However, beyond their influence, they had to find a popular cause, shared by those who followed them; they found it under the claim that Spaniards should be banished from Buenos Aires. This was the first requirement of the petition they presented, while the eviction of the radical deputies from the junta appeared under this in the list. All the demands were approved (although the measure against the Spaniards was not later implemented). ${ }^{32}$

28 With regard to the celebrations, see mainly Lía Munilla, Celebrar y Gobernar. Un estudio de las fiestas cívicas en Buenos Aires, 1810-1835 (Buenos Aires: Miño Dávila Editores, 2013); Fernando Gómez, "Las Fiestas Mayas y la construcción de legitimidad en Buenos Aires (1811-1836)", Prohistoria 19 (2013): 73-93.

29 For a recent approach to this classical topic, see Noemí Goldman, Mariano Moreno. De reformista a insurgente (Buenos Aires: Edhasa, 2016).

30 Ignacio Núñez, "Noticias históricas", Biblioteca de Mayo, 25 Vols. (Buenos Aires, 1960), I, 453 .

31 Di Meglio, ¡Viva el bajo pueblo!, 101.

32 The petition was reproduced entirely in the press on 15 April 1811. Gaceta de Buenos Aires (1810-1821), T II (Buenos Aires, 1910), 281-293. 
This event was a turning point in the revolution. First, the petition was made in the name of a single actor: "the People of Buenos Aires". An opponent of the movement wrote in his diary that the "plebe" had been erroneously considered as the people (pueblo). Instead, "whether the President had called the true People, he would not have achieved his plans". ${ }^{33}$ Only a small number of neighbours, and not the plebeians of the suburbs, were the "people" in the colonial period. Now, the concept had been expanded to include any man (not women, although many of them participated in this new political life). In a revolution justified from the beginning in the name of "the people", this was a transformation.

Second, the leaders needed a topic that would be popular enough to drive plebeians into action. Thus, in every subsequent mobilization, the leaders had to include popular mottos to gain support, which meant a way of including popular demands in the political struggle. That happened on 5 April 1811: the moderate deputies had never spoken against the Spaniards, but this mobilization was mainly against them. In 1810, the revolutionaries had protested against the colonial authorities and the abuses of the metropolis, while recognizing Ferdinand VII as the legitimate king. Now things had changed: every Spaniard was an enemy. This was the third change on that crucial day, caused by the plebeian intervention. Resentment against the Europeans, as they were called, was common among the plebeians, given the better conditions they generally enjoyed when they migrated to Buenos Aires, such as communitarian aid, availability of credit, better opportunities from marriage (marrying a Spaniard was more prestigious for a woman) and different legal punishments for the same offence. None of this led to the revolution, but when it started, the small complaints became politicized.

There was a fourth lesson from the movement of April 1811: it was successful. All the political groups learnt that the combination of plebeians and troops in the Plaza de la Victoria amounted to a winning formula. In September 1811, a new faction dissolved the junta and created a triumvirate instead, using the same political practice: "Plebe in the Plaza and troops supporting it", as a contemporary put it. ${ }^{34}$ Similar movements occurred in October 1812, when the radicals seized power, and in April 1815, when they lost it. There is not enough space here to describe all these events, but it is clear that plebeian mobilization became a feature of Buenos Aires' politics. ${ }^{35}$

33 Juan Manuel Beruti, Memorias curiosas (Buenos Aires: Emecé Editores, 2001), 166.

34 "Instrucción de Saavedra a Juan de la Rosa Alba", Biblioteca de Mayo, II, vol. 1 (196o): 1122.

35 Di Meglio, ;Viva el bajo pueblo! 
Those who had been in subaltern positions in colonial times found an opportunity to rise socially through supporting the new cause; a new place in the community. Through their struggle in the revolution, they were symbolically levelled: they now were more valuable than those who had opposed it, even if the latter had held a higher social status. Social and racial tensions were subsumed in the opposition to the Spaniards. In a society based on the notion of juridical inequality by colour and place of birth, the possibility of changing this, and at the same time overpowering the enemies of the cause, was a powerful motive for plebeians. Therefore, they were the main denouncers of "enemies of the system", mostly Spaniards, to a "Tribunal of Public Safety" created after the movement of April $1811 .^{36}$

The differences between autonomists and independentists were resolved by the defeat of Napoleon in Europe and the return of Ferdinand vir to the throne in 1814. The king was not willing to negotiate over autonomy. Instead, he sent troops, enabling local loyalists to prevail in most of the continent. By 1816 , the only insurgent territory still standing was the Rio de la Plata. Therefore, when a congress was called that year, independence was declared without hesitation. The war against the loyalists - in Chile and in the Upper Peru - nevertheless lasted for years, and in addition, there were military clashes between two different revolutionary blocks after 1814. The Banda Oriental, Entre Ríos, Santa Fe and two other provinces created a confederation against the central revolutionary government located in Buenos Aires. ${ }^{37}$

Although in the latter, labour relations were not openly contested, the political disputes and military mobilizations had an impact on them. First, there was plebeian pressure to ensure that every job was given to the "sons of the country". Second, slavery was contested. ${ }^{38}$ Both radical and moderate branches maintained their position against slavery, and decided to gradually put an end to it. They avoided direct emancipation, claiming that slaves were not prepared for sudden freedom, and thereby protecting property rights. They started with the slave traffic. In May 1812, the official journal proclaimed:

How long shall we give shelter in our ports to these ships, loaded with parents, with children, with husbands who, traitorously wrenched from the bosom of their families, come to satisfy with their sad existence the

$36 \quad$ Ibid.

37 For a synthesis of this, see Gabriela Tio Vallejo, "Rupturas precoces y legalidades provisorias: el fin del poder español en el Río de la Plata”, Ayer 74 (2009): 133-162. 
greed, and the caprices of their barbarous robbers? Shame on a free people, if it is indifferent to these excesses. ${ }^{39}$

The triumvirate banned the traffic. Any new slave who landed in what now was called the United Provinces of the Rio de la Plata would be freed. This decision reinforced the slaves' support for the revolution. Shortly after the measure was put in place, a slave called Ventura denounced a counterrevolutionary conspiracy by Spaniards, many of whom were executed after a short trial. During the agitation of these days, another slave called Valerio said to his master that he thought Criollos, Blacks and Indians were equal. ${ }^{40}$

A few months later, under a new government, the 1813 Constituent Assembly enacted a Free Womb Act, under which any new-born child of a slave mother was to be born free. The idea was that by abolishing slavery and the slave trade by inheritance, the institution would eventually disappear when the last person enslaved before 1813 died, all without interfering with the owners' interests. However, slaves did not want to wait for freedom any longer. Many believed abolition was close: a black "poor journeyman" named Hilarión Gómez declared "everything breathes banishing slavery". ${ }^{41}$

For men, the revolutionary war itself opened up a direct route out of slavery. If they became soldiers, they were promised that they would be set free by the end of the conflict, and many wanted to go into the army. In 1816, a woman demanded that the authorities pay her the value of a "mulatto" she owned, who had escaped and enlisted. Another owner stated that he had a young slave, who showed "a strong desire to pursue a military career", so the owner wanted to be paid for him by the state. ${ }^{42}$ Cases like these were common, and many slaves were bought by the authorities. Thirty per cent of the soldiers in the decisive Army of the Andes led by General José de San Martín in 1817 were

39 15 May 1812. Gaceta de Buenos Aires (1810-1821), T. III (Buenos Aires, 1910), 192-193.

40 All the information comes from the Archivo General de la Nación [AGN, Argentine National Archive], sala X, legajo 6-7-4, Conspiración de Álzaga. See also Mariana Pérez, “¡Viva España y mueran los patricios! La conspiración de Álzaga de 1812”, Americanía, no. 3 (2013): 21-55.

41 AGN, X, 8-9-4, Solicitudes Civiles y Militares, 1815. For the judicial fights of slaves in the 1810s, see Gladys Perri, "Los esclavos frente a la justicia. Resistencia y adaptación en Buenos Aires, 1780-1830", in La ley es tela de araña. Ley, justicia y sociedad rural en Buenos Aires, 1780-1830, ed. Raúl Fradkin (Buenos Aires: Prometeo libros, 2009), 51-82; Magdalena Candioti, "Altaneros y libertinos. Transformaciones de la condición jurídica de los afroporteños en la Buenos Aires revolucionaria (1810-1820)", Desarrollo Económico 5o, no. 198 (2010): 271-296.

Mauricia Arguibel and José Ortiz, both in AGN, X, 09-02-04, Solicitudes Civiles. 
former slaves. ${ }^{43}$ Becoming a soldier gave Afro-descendants a strong identification with the homeland (Patria). It gave them freedom and respectability, or at least they expected it to. In 1820, a drunken white officer insulted one of his subalterns and called him "black". He replied loudly that the officer had no right to offend him: "I am black but I am a corporal of the Patria". His fellow soldiers were so angry that they almost rebelled against the officer. ${ }^{44}$ One consequence of this military manumission was that after the war there were more slave women than men. Greatly weakened, slavery continued to exist until its abolition by the 1853 National Constitution, but it could no longer supply the labour power for rural production and the domestic labour required. 45

Another substantial change came with the sanctioning of free trade by the revolutionary governments, a measure that had enduring consequences. While it made foreign goods cheaper, and thus available to workers, it was also contested by artisans, whose workshops were threatened by the entry of those manufactures. However, these criticisms did not change the artisans' support for the revolutionary cause. ${ }^{46}$

In the Banda Oriental and Entre Ríos - as we have already seen, an area with many conflicts concerning land - peasants and labourers mobilized for revolution. Loyalist forces had been sent from Montevideo to control the rural areas in 1810, but in February 1811 a massive uprising started there in support of the Buenos Aires' junta. The rebels were successful, obliging the counterrevolutionary troops to abandon the countryside and look for shelter in Montevideo (which remained a loyalist stronghold until it fell in 1814). ${ }^{47}$

43 San Martín's army crossed the Andes and defeated the royalist forces in Chile, securing its independence. Later San Martín led his troops to Perú, centre of the royal power in South America.

44 AGN, X, 29-10-2, Sumarios Militares, 146.

45 See George Reid Andrews, The Afro-Argentines of Buenos Aires, 1800-19oo (Madison: University of Wisconsin Press, 1980). See also the works published in "Negros de la patria": Los afrodescendientes en las luchas por la independencia en el antiguo Virreinato del Río de la Plata, ed. Silvia Mallo and Ignacio Telesca (Buenos Aires: Sb editorial, 2010); Peter Blanchard, Under the Flags of Freedom: Slave Soldiers and the Wars of Independence in Spanish South America (Pittsburgh: University of Pittsburgh Press, 20o8); Di Meglio, ¡Viva el bajo pueblo!

46 See Jonathan Brown, A Socioeconomic History of Argentina, 1776-1860 (Cambridge: Cambridge University Press, 1979). Also, Di Meglio, $j$ Viva el bajo pueblo! This is a topic that deserves further research.

47 Ana Frega, Pueblos y soberanía en la revolución artiguista: La región de Santo Domingo Soriano desde fines de la colonia hasta la ocupación portuguesa (Montevideo: Ediciones de la Banda Oriental, 2007). 
This rural movement was led by José Artigas, and took the most radical positions in the whole area. Many peasants and labourers fought for liberty and egalitarianism, first against Spaniards and local loyalists, and subsequently after 1814 - against the Buenos Aires central government. The motto of these Artiguists was "nadie es más que nadie" ("nobody is more than nobody"). They demanded land reform and affirmed their traditional common rights should be respected. In 1815, Artigas sanctioned a land reform, confiscating the properties of loyalist landowners and dividing it among poor families, whom he called "the unhappy ones". The decision was not just a benevolent gesture from Artigas: his troops had pressed him to be given some benefit for having fought without pause under his command. With the new measures, some of these peasants and labourers would become landowners. ${ }^{48}$

Many members of the elites saw Artiguism as a menace. Nicolás Herrera, a well-to-do politician from Montevideo, wrote to the Portuguese Court in Brazil, promoting action against Artigas:

The white caste occupied in America the same place the nobility did in the states of Europe, and it produced the same effect. But the revolution divided whites. The Spanish Europeans and their Party were presented as criminals, inept, cowards, and barbarians to the Creoles. Indians, blacks and mulattos became used to mistreat their masters and employers. ... The dogma of equality moves the crowd against all government and has established a war between the poor and the rich, master and lord; those who command and those who obey. ${ }^{49}$

The Portuguese invasion of the Banda Oriental began in 1816. The Artiguists resisted for four years, but they were ultimately defeated and the process of land reform was interrupted. In that same year, 1820, the central government created in 1810 collapsed in Buenos Aires. For a while, provinces governed themselves without any authority from above.

Some important changes had taken place by then. The monarchy had been abolished and the former subjects now lived in republics. Some liberal reforms had also been made, such as sweeping away noble titles, the Inquisition, judicial torture and the indigenous tribute that had existed in colonial times outside the region considered here. Soon, the properties of the Catholic regular

48 Ana Frega, "El Reglamento de Tierras de 1815: justicia revolucionaria y virtud republicana", in Tierras, reglamento y revolución: Reflexiones a doscientos años del reglamento artiguista de 1815, ed. Gerardo Caetano y Ana Ribeiro (Montevideo: Planeta, 2015). 
orders were secularized in Buenos Aires. The "caste system" was also ended with the revolution, putting an end to juridical racial inequality (although racism persisted). However, most popular expectations of an egalitarian transformation were not achieved.

The demise of revolutionary enthusiasm can be adequately traced through the literature of the time. One of the innovations of that agitated period was the appearance of a new literary genre, strongly political, in which some writers used the language of the people of the countryside and placed them as central historical actors. In a poem written in 1821, two gauchos complain about justice. One says that a wealthy man who steals public money is quickly released, while any peasant who steals something for eating is hit and imprisoned by the police. "And they call this Equality?"

\section{Labour Relations after the Revolution}

The War of Independence triggered a remarkable destruction of wealth and trading networks. Potosí remained in loyalist hands until the end of the conflict in 1825 , and it also experienced a crisis in mining, partially caused by the refusal of the indigenous communities of that area to continue with the coercive mita system after the revolution. Thus, silver stopped being the main commodity exported from Buenos Aires, as it had been before 1810, and Potosí ceased to be a hub of demand for different goods. The new situation had dire consequences in the interior of present-day Argentina. However, in the Pampas region, with good fluvial connections with the Atlantic, free trade provided new opportunities. ${ }^{51}$

In colonial times, commerce had been the most profitable activity in Buenos Aires, ${ }^{52}$ but after the revolution, the new transatlantic trade was mainly in the hands of British merchants. Therefore, former Buenos Aires merchants,

50 It is a poem called "Diálogo patriótico interesante entre Jacinto Chano, capataz de una estancia en las Islas del Tordillo, y el gaucho de la guardia del Monte", by Bartolomé Hidalgo. In Bartolomé Hidalgo, Cielitos y diálogos patrióticos (Buenos Aires: Editorial Huemul, 1967). See Josefina Ludmer, The gaucho genre: A treatise on the motherland (Durham and London: Duke University Press, 2002).

51 Carlos Sempat Assadourian, "El sector exportador de una economía regional del interior argentino. Córdoba, 1800 - 1860", in El sistema de la economía colonial, ed. Carlos Sempat Assadourian (México: Editorial Nueva Imagen, 1983), 18-55; Tandeter, Coacción y mercado.

52 Susan Socolow, Merchants of Buenos Aires 1778-1810: Family and Commerce (Cambridge: Cambridge University Press, 1978). 
who could not compete with the British, moved their capital to cattle raising, which required low initial investment. Hides and salted meat became the main commodities. The Banda Oriental, Entre Ríos and Santa Fe were the main producers of hides before 1810, but their livestock staple was seriously diminished during the war. By contrast, Buenos Aires had suffered little combat in its territory in the previous years and was ready to take advantage. ${ }^{53}$ Thanks to rapid economic growth, Buenos Aires consolidated its privileged situation among the rest of the provinces. Trade was far more extensive than in other regions, and this was the activity through which the provincial states were financed. The annual budget of Buenos Aires often surpassed that of all the other provinces combined. ${ }^{54}$

To ensure economic expansion, the government of Buenos Aires started to put pressure on the frontier to gain land controlled by the indigenous sovereign groups, which had never been conquered by the Spaniards. As the War of Independence was over, it could use its military forces in the frontier region. At the same time, the state rented out huge expanses of public land at very low prices, allowing many members of the elite to acquire large landholdings for exploitation. The province tripled the area of arable land, and a powerful landowning class with large landholdings quickly formed, particularly in the southern areas taken from the indigenous population. ${ }^{55}$

If land was not a problem for these now powerful cattle ranchers, labour was. There was a chronic shortage, not only because of the scarcity of population but also due to the persistence of a large number of small and mediumsize producers. Many peasants produced for the market and did not need wages. In addition, the growing engagement with international markets led to the emergence of a group of relatively prosperous new agricultural tenants. ${ }^{56}$ Because the scarce population of the Pampas combined with the high demand for labour led to high wages, constant migration from the interior provinces provided new workers. However, migration alone was not enough to cover the increased demands of the major estancias. On the one hand, militarization brought about by the previous war and the continuing conflicts in the

53 Tulio Halperin Donghi, "La Expansión Ganadera en la Campaña de Buenos Aires (1810 1852)", Desarrollo Económico 3, no. 1-2 (1963): 57-110.

54 Jorge Gelman, "La gran divergencia. Las economías regionales en Argentina después de la independencia", in La historia económica y los procesos de independencia en la América hispana, ed. Susana Bandieri (Buenos Aires: Prometeo Libros, 2010), 105-129.

55 Halperin Donghi, "La Expansión Ganadera".

56 Julio Djenderedjian, Historia del capitalismo agrario pampeano: la agricultura pampeana en la primera mitad del siglo XIX (Buenos Aires: siglo veintiuno editores, 2008). 
following years meant that soldiers were required. On the other hand, as land was still accessible for these migrants, they could become peasants, as had been the case in colonial times. Thus, the persistence of small landholding acted as a barrier to proletarianization. ${ }^{57}$

In the 1820 , cattle ranchers therefore aspired to put an end to the opportunities to create small farms, at the same time trying to secure their own property rights, which were challenged by the occupation of land and by customary rural practices. Most tenants had verbal contracts. Custom sanctioned that those staying on a piece of land acquired rights of possession over it, at the same time having the first option to purchase. The owners encouraged new written contracts, without regard to the previous occupants. Although the provincial state protected landowners, at a lower level of jurisdiction the two contradictory concepts of entitlement to the land often collided, since members of the community would recognize continuous possession over time, if held with "honesty" and without generating conflicts, as equivalent to the access to property. At the same time, those who had been tenants for an extended period became neighbours of the community, which provided protection and allowed them to defend themselves. ${ }^{58}$

Major cattle ranchers and the state faced great difficulties when confronting pre-existing forms of land occupancy that had unintentionally been reinforced by the revolution. They were also unable to fully achieve their goals regarding wage labourers. The pressure on "vagrants" increased in every province: any man without papers showing he had a contract could be sent into the army. At the same time, the authorities tried to eliminate the extended forms of subsistence that were alternatives to wage labour. A list of instructions for the administrators of estancias written in 1819 emphasized two important points. First, families had to be prevented from settling on a property, thus making it impossible for them to become peasants. Second, the hunting of otters, rheas and rodents by wage workers for personal consumption had to be stopped. ${ }^{59}$ However, the scarcity of workers and the easy access to land, combined with

57 Garavaglia, Pastores y labradores; Tulio Halperin Donghi, "Clase terrateniente y poder político en Buenos Aires (1820-1930)”, Cuadernos de Historia Regional 15 (1995): 11-46.

58 Raúl Fradkin, "La experiencia de la justicia: Estado, propietarios y arrendatarios en la frontera bonaerense (180o-1830)", in La ley es tela de araña, comp. Raúl Fradkin; Jorge Gelman, "Derechos de propiedad, crecimiento económico y desigualdad en la región pampeana, siglos XVIII y XIX”, Historia Agraria 37 (2005): 467-488.

59 Juan Manuel de Rosas, Instrucciones a los mayordomos de estancias (Buenos Aires: Claridad, 2010). Before entering politics, Rosas, who was to become a key figure in the region, was a rancher and wrote these rules in 1819 . 
the low repressive capacity of the state, allowed members of the popular classes to continue these customary practices for decades. Therefore, wage workers retained much of their autonomy and could leave once they had acquired a sum that seemed sufficient, or if they were discontent with their employer. ${ }^{60}$ Strikes, described at the time as "mutinies" or "uprisings", also occurred. Such actions were not created by the revolution, but the political experience of the previous years allowed the popular classes to deal better with the attacks from above.

The pressure of the authorities on behalf of the landowners' interests was greater after the revolution than before in Buenos Aires, and similar to the late colonial situation in the Banda Oriental. However, the popular mobilization that had started in the 1810 s strengthened the possibilities of defying the offensives by the ruling classes and the state. Hence, by holding on to notions of justice carried over from colonial times, many tenants, farmers and small cattle ranchers could successfully resist the advance of property rights and maintain their holdings. In addition, they could fall back on forms of collective action related to the new political circumstances and the militarization brought by the revolution.

For example, in 1822, in the northern part of the province of Buenos Aires, a landowner wanted to evict what he called a group of "vagrants". The judge who took the case held a different view: he considered the occupants "a multitude of militiamen", who were from Santa Fe and whose services during the War of Independence had been rewarded by the government by granting them access to those lands, without title and without paying a fee. The occupants in turn delayed the eviction and continued sowing. They designated one of their own to be their representative and proposed paying a lease, but did not accept they had to leave. Neighbours of the land recommended that the violent eviction should not go ahead, because "we fear montonera", referring to a group of armed riders that had played an important role in the War of Independence in the region. Four years later, the dispute had still not been resolved and the judge declared: "I have not proceeded by force because I do not have it and it could bring fatal consequences", given that "there are more than fifty men with their respective families and all are armed, because they are soldiers of the active State Militia". Thus, being part of the militia allowed the occupants to

6o Garavaglia, Pastores y labradores; Jorge Gelman, "Un gigante con pies de barro: Rosas y los pobladores de la campaña", in Caudillismos rioplatenses: Nuevas miradas a un viejo problema, comps. Noemí Goldman and Ricardo Salvatore (Buenos Aires: Eudeba, 1998), 223-240. 
maintain their position as peasants, a status they had won in the revolutionary years. ${ }^{61}$

The long war had brought changes in the whole area, affecting labour relations. Peasants, labourers and other plebeians entered the ranks of the army and the militia, which became major employers of the soldiers and wage workers. Military experience gave them new knowledge, which nourished their capacity for protest and prepared them for political intervention. Desertions and mutinies were common practice among the troops, with wages, food, clothing and mistreatment by officers being the causes of discontent. What was in dispute included the work performed by the soldiers, their remuneration and the conditions of service. ${ }^{62}$

However, the main transformation in labour relations in the region brought about by the revolution was the serious weakening of slavery. The large estancias had to deal with the need to replace slaves, who had been used to perform fundamental tasks before the revolution. Some attempted to replace them with other forms of forced labour. The establishments of Juan Manuel de Rosas - who was also a key political figure from the 1820 s to the $1850 \mathrm{os}$ - are an excellent example. In the 183 os, he tried to replace former slaves by captive Indians, who suffered similar conditions to those previously experienced by slaves. They did not receive a salary but were given food, and this "payment" was much lower than that received by wage workers. However, by the end of the decade, the captives had managed to renegotiate their situation and had obtained conditions similar to those of wage earners. In the 1840s, Rosas therefore turned to the use of indentured labourers from Galicia, in Spain. He would pay for their expensive Atlantic travel, and this money was then deducted from their salaries until the debt had been fully settled, when they became free labourers. Cattle ranchers were able to pay these immigrants much lower salaries than the locals. Like slaves and captives, Galicians carried out the permanent tasks on the estancias, but within a short period they were able to renegotiate their working conditions. The attempt to replace slavery with other forms of coerced labour thus had little success. Major cattle ranchers became entirely dependent on free wage labour and the small producers managed to preserve their place in the productive system and even to expand it. ${ }^{63}$

61 Raúl Fradkin, “¿'Facinerosos’ contra 'cajetillas’? La conflictividad rural en Buenos Aires durante la década de 1820 y las montoneras federales", Illes i Imperis, no. 4 (2001): 5-34.

62 Gabriel Di Meglio, Raúl Fradkin and Florencia Thul, “¿Huelgas antes de los sindicatos? Notas para una historia larga de las luchas de los trabajadores en Argentina y Uruguay", Archivos de historia del movimiento obrero y la izquierda, no. 14 (2019): 11-31.

63 Jorge Gelman, "El fracaso de los sistemas de trabajo coactivo rural en Buenos Aires bajo el rosismo", Revista de Indias, vol. LIX, no. 215 (1999): 123-141. 
The revolutionary legacy for the popular classes in the region was not only that they could act collectively on certain occasions, but also that they had become important actors in the new republican politics. From the 1820 on onwards, every province organized elections to choose the members of its legislature, which appointed the governor. Male suffrage was extended after the revolution: in Buenos Aires every free man could vote once he had passed the age of 21, without any other requirement. ${ }^{64}$ This political system, and the practice of mobilization of the urban and rural population after the 181os, made many leaders attentive to popular claims in order to gain support. They had to take into account the interests of rural peasants, urban artisans and the Afro-descendant community, organized in the 1820 s in the so-called "African Societies". With some nuances, the situation was similar throughout the whole region.

\section{4}

\section{Conclusions}

Most historiography on the Latin American revolutions of the early nineteenth century has understood them primarily as political events that led to the creation of new independent countries. Recent studies have shifted the focus to the social aspects of those revolutions, as this chapter has done for the case of the Pampas, in present-day Argentina. Meanwhile, students of labour relations have adopted a long-term perspective to explore the development of "agrarian capitalism".

This chapter has created a conversation between the two lines of inquiry. One evident conclusion from this is that there is still much research to be done. For example, we know very little about what the world of artisans' workshops was like after the 1810s. Yet from what we know so far, labour relations seem not to have been seriously transformed by the revolution in the short term, with one major exception: slavery. Much weakened during the revolutionary years, slavery never recovered, and the attempts to replace it with other forms of coercive labour failed.

While slavery was openly contested during the revolutionary years, other labour relations were not. Instead, the popular classes seem to have had a different agenda. In the Banda Oriental, peasants and labourers aimed to maintain their customary use of resources and access to land. Elsewhere in the region,

64 Marcela Ternavasio, La revolución del voto. Política y elecciones en Buenos Aires, 1810-1852 (Buenos Aires: Siglo XXI, 2001). 
members of the popular classes challenged social and racial hierarchies - tacitly contesting the colonial caste system and advocating for every man to have political rights. It was not the popular classes but the elites who tried to change labour relations. They wanted to strengthen their control over the rural and the urban poor, and to be able to have access to fluid and cheaper labour. Starting in the 1820s, cattle ranchers and the provincial state aspired to reinforce property rights in Buenos Aires. However, to a great extent they failed, due to the resistance of many peasants.

That was the legacy of the political and military mobilization of the revolutionary years: it strengthened workers and allowed them to withstand the attacks that the new order directed at them. After the revolutionary years, leaders had to take some of their demands and opinions into account. The popular classes thus managed to maintain some customary practices for decades and to negotiate their labour conditions, taking advantage of structural factors, such as the scarcity of the labour force and the existence of an open frontier. ${ }^{65}$ Some of the key features of the development of the Argentine "agrarian capitalism" - such as high wages and limited proletarianization - were shaped by the politicization of the popular classes in the 181os.

\section{Bibliography}

Andrews, George Reid, The Afro-Argentines of Buenos Aires, 1800-190o (Madison: University of Wisconsin Press, 1980).

Amaral, Samuel, The Rise of capitalism on the Pampas: The Estancias of Buenos Aires, 1785-1870 (Cambridge: Cambridge University Press, 1998).

Archivo Artigas, t. Xxx, (Montevideo: Imprenta Ecler S.A., 1998).

Barral, María Elena, Raúl Fradkin, Gladys Perri, and Fabián Alonso, "Los vagos de la campaña bonaerense: la construcción histórica de una figura delictiva (1780-1830)", in El poder y la vara. Estudios sobre la justicia y la construcción del Estado en el Buenos Aires rural, comp. Raúl Fradkin (Buenos Aires: Prometeo Libros Editorial, 2007), 99-128.

Barrán, José Pedro, and Benjamín Nahum, Bases económicas de la revolución artiguista (Montevideo: Ediciones de la Banda Oriental, 2007).

Barsky, Osvaldo, and Julio Djenderedjian, Historia del capitalismo agrario pampeano: La expansión ganadera hasta 1895 (Buenos Aires: Universidad de Belgrano, 2003).

65 Raúl Fradkin, “¿Qué tuvo de revolucionaria la revolución de independencia?” Nuevo Topo. Revista de historia y pensamiento crítico, no. 5 (2008): 15-43. 
Belsunce, César García, Buenos Aires. Su gente. 180o-1830, 3 Vols. (Buenos Aires: Emecé Distribuidora, 1976).

Bernaldo, Pilar González, "Producción de una nueva legitimidad: ejército y sociedades patrióticas en Buenos Aires entre 1810 y 1813", in AAVV, Imagen y recepción de la Revolución Francesa en la Argentina (1990): 27-51.

Bernaldo, Pilar González, "La 'identidad nacional' en el Río de la Plata postcolonial:Continuidades y rupturas con el Antiguo Régimen”, Anuario IEHS 12 (1997): 109-122.

Beruti, Juan Manuel, Memorias curiosas (Buenos Aires: Emecé Editores, 2001).

Biblioteca de Mayo. Colección De Obras y Documentos Para La Historia Argentina, 25 Vols. (Buenos Aires, 196o-1963).

Blanchard, Peter, Under the Flags of Freedom: Slave Soldiers and the Wars of Independence in Spanish South America (Pittsburgh: University of Pittsburgh Press, 2008).

Borucki, Alex, From Shipmates to Soldiers. Emerging Black Identities in the Río de la Plata (Albuquerque: University of New Mexico Press, 2015).

Brown, Jonathan, A Socioeconomic History of Argentina, 1776-1860 (Cambridge: Cambridge University Press, 1979).

Campi, Daniel, "Trabajo, azúcar, disciplinamiento y resistencia: El caso de Tucumán, Argentina (segunda mitad del siglo XIX)", in Historia do Açúcar: Fiscalidade, metrologia, vida material e patrimonio, ed. Alberto Viera et al. (Funchal: CeHa, 2006), 187-215.

Candioti, Magdalena, "Altaneros y libertinos. Transformaciones de la condición jurídica de los afroporteños en la Buenos Aires revolucionaria (1810-1820)", Desarrollo Económico 50, no. 198 (2010): 271-296.

Canedo, Mariana, Propietarios, ocupantes y pobladores: San Nicolás de los Arroyos, 1600-1860 (Mar del Plata: Universidad Nacional de Mar del Plata, 2000).

Chiaramonte, José Carlos, Formas de sociedad y economía en Hispanoamérica (Buenos Aires: Grijalbo, 1984).

Chiaramonte, José Carlos, Ciudades, provincias, Estados: Orígenes de la Nación Argentina (1800-1846) (Buenos Aires: Editora Espasa Calpe Argentina, 1998).

Chiaramonte, José Carlos, Fundamentos intelectuales y políticos de las independencias. Notas para una nueva historia intelectual de Iberoamérica (Buenos Aires: Teseo, 2010).

Di Meglio, Gabriel, ;Viva el bajo pueblo! La plebe urbana de Buenos Aires y la política entre la Revolución de Mayo y el rosismo (Buenos Aires: Prometeo Libros, 20o6).

Di Meglio, Gabriel, Raúl Fradkin, and Florencia Thul, “¿Huelgas antes de los sindicatos? Notas para una historia larga de las luchas de los trabajadores en Argentina y Uruguay", Archivos de historia del movimiento obrero y la izquierda, no. 14 (2019): 11-31.

Djenderedjian, Julio, Historia del capitalismo agrario pampeano: la agricultura pampeana en la primera mitad del siglo XIX (Buenos Aires: siglo veintiuno editores, 2008).

Fradkin, Raúl, "Entre la ley y la práctica: la costumbre en la campaña bonaerense de la primera mitad del siglo XIX", Anuario IE HS 12 (1997): 141-156. 
Fradkin, Raúl, “¿'Facinerosos’ contra 'cajetillas’? La conflictividad rural en Buenos Aires durante la década de 1820 y las montoneras federales", Illes i Imperis, no. 4 (2001): 5-34.

Fradkin, Raúl, "La experiencia de la justicia: Estado, propietarios y arrendatarios en la frontera bonaerense (1800-1830)", in La ley es tela de araña. Ley, justicia y sociedad rural en Buenos Aires, 1780-1830, ed. Raúl Fradkin (Buenos Aires: Prometeo libros, 2009), 83-120.

Fradkin, Raúl, ¿Y el pueblo dónde está? Contribuciones para una historia popular de la Revolución de independencia en el Río de la Plata (Buenos Aires: Prometeo Libros, 2008).

Fradkin, Raúl, “¿Qué tuvo de revolucionaria la revolución de independencia?” Nuevo Topo. Revista de historia y pensamiento crítico, no. 5 (2008): 15-43.

Fradkin, Raúl, "La revolución en los pueblos del litoral rioplatense", Estudios IberoAmericanos 36, no. 2 (2010): 242-265.

Frank, Andre Gunder, Capitalism and Underdevelopment in Latin America: Historical Studies of Chile and Brazil (New York: Monthly Review Press, 1967).

Frega, Ana, Pueblos y soberanía en la revolución artiguista: La región de Santo Domingo Soriano desde fines de la colonia hasta la ocupación portuguesa (Montevideo: Ediciones de la Banda Oriental, 2007).

Frega, Ana, "El Reglamento de Tierras de 1815: justicia revolucionaria y virtud republicana", in Tierras, reglamento y revolución: Reflexiones a doscientos años del reglamento artiguista de 1815, ed. Gerardo Caetano y Ana Ribeiro (Montevideo: Planeta, 2015), 487-533.

Garavaglia, Juan Carlos, "El pan de cada día: el mercado del trigo en Buenos Aires, 1700-1820", Boletín del Instituto de Historia Argentina y Americana, "Dr. Emilio Ravignani" no. 4, (1991): 7-29.

Garavaglia, Juan Carlos, Pastores y labradores de Buenos Aires: una historia agraria de la campaña bonaerense 1700-1830 (Buenos Aires: Ediciones de la Flor, 1999).

Garavaglia, Juan Carlos, "De Caseros a la guerra del Paraguay: el disciplinamiento de la población campesina en el Buenos Aires postrosista (1852-1865)", Illes i Imperis, no. 5 (2001): $53^{-80}$.

Garavaglia, Juan Carlos, and Jorge Gelman, "Rural History of the Rio de la Plata, 16oo1850: results of a historiographical renaissance", Latin American Research Review 30 , no. 3 (1995): $75^{-105 .}$

Gelman, Jorge, Campesinos y estancieros: Una región del Rio de la Plata a fines de la época colonial (Buenos Aires: Editorial Los Libros del Riel, 1998).

Gelman, Jorge, "Un gigante con pies de barro: Rosas y los pobladores de la campaña”, in Caudillismos rioplatenses: Nuevas miradas a un viejo problema, comps. Noemí Goldman and Ricardo Salvatore (Buenos Aires: Eudeba, 1998), 223-240. 
Gelman, Jorge, "El fracaso de los sistemas de trabajo coactivo rural en Buenos Aires bajo el rosismo", Revista de Indias, vol. LIX, no. 215 (1999): 123-141.

Gelman, Jorge, "Derechos de propiedad, crecimiento económico y desigualdad en la región pampeana, siglos XVIII y XIX”, Historia Agraria 37 (2005): 467-488.

Gelman, Jorge, "La gran divergencia. Las economías regionales en Argentina después de la independencia”, in La historia económica y los procesos de independencia en la América hispana, ed. Susana Bandieri (Buenos Aires: Prometeo Libros, 2010), 105-129.

Gelman, Jorge, "De la historia agraria a la historia de las desigualdades. Un recorrido y varios homenajes", Anuario IEHS 32, no. 2 (2017): 47-58.

Goldberg, Marta, and Silvia Mallo, "La población africana en Buenos Aires y su campaña. Formas de vida y subsistencia, 1750-1850", Temas de Asia y África, no. 2 (1994): 15-69.

Goldman, Noemí, “Buenos Aires, 1810: la 'revolución', el dilema de la legitimidad y de las representaciones de la soberanía del pueblo", Historia y política: Ideas, procesos y movimientos sociales 24 (2010): 47-69.

Goldman, Noemí, Mariano Moreno. De reformista a insurgente (Buenos Aires: Edhasa, 2016).

Goldman, Noemí, and Fabio Wasserman "Un balance de la historia política y de la construcción de identidades en el proceso de independencia", Investigaciones y Ensayos 62 (2016): $23-46$.

Gómez, Fernando, "Las Fiestas Mayas y la construcción de legitimidad en Buenos Aires (1811-1836)", Prohistoria 19 (2013): 73-93.

Guerra, François-Xavier, Modernidad e independencias: Ensayos sobre las revoluciones hispánicas (Madrid: Ediciones Encuentro, 1992).

Halperin Donghi, Tulio, "La Expansión Ganadera en la Campaña de Buenos Aires (1810 - 1852)", Desarrollo Económico 3, no. 1-2 (1963): 57-110.

Halperin Donghi, Tulio, "Revolutionary Militarization in Buenos Aires, 1806-1815", Past \& Present 40, no.1 (1968): 84-107.

Halperin Donghi, Tulio, Politics, Economics and Society in Argentina in the Revolutionary Period (New York: Cambridge University Press, 1975).

Halperin Donghi, Tulio, Reforma y Disolución de los Imperios Ibéricos, 1750-1850 (Madrid: Alianza editorial, 1985).

Halperin Donghi, Tulio, "Clase terrateniente y poder político en Buenos Aires (18201930)", Cuadernos de Historia Regional 15 (1995): 11-46.

Hidalgo, Bartolomé, Cielitos y diálogos patrióticos (Buenos Aires: Editorial Huemul, 1967).

Hora, Roy, Historia económica de la Argentina en el siglo XIX (Buenos Aires: Siglo XXI/ Fundación OSDE, 2010). 
Johnson, Lyman, Workshop of Revolution: Plebeian Buenos Aires and the Atlantic World, 1776-1810 (Durham: Duke University Press, 2011).

Ludmer, Josefina, The gaucho genre: A treatise on the motherland (Durham and London: Duke University Press, 2002).

Madrazo, Guillermo, Hacienda y encomienda en los Andes. La puna argentina bajo el marquesado de Tojo. Siglos XVII a XIX (Buenos Aires: Fondo Editorial, 1982).

Mallo, Silvia, and Ignacio Telesca, ed., "Negros de la patria": Los afrodescendientes en las luchas por la independencia en el antiguo Virreinato del Río de la Plata, (Buenos Aires: Sb editorial, 2010).

Mandrini, Raúl, La Argentina aborigen (Buenos Aires: Siglo xxi Editores, 2008).

Martínez Dougnac, Gabriela, "Justicia colonial, orden social y peonaje obligatorio", in Poder Terrateniente, relaciones de producción y orden colonial, ed. Azcuy Ameghino (Buenos Aires: F. García Cambeiro, 1996), 185-225.

Mata, Sara, "Estructura agraria, la propiedad de la tierra en el Valle de Lerma, Valle Calchaquí y la Frontera Este (1750-180o)", Andes. Antropología e Historia, no. 1 (1990): 47-88.

Mata, Sara, Los gauchos de Güemes: Guerras de independencia y conflicto social (Buenos Aires: Sudamericana, 2008).

Mateo, José, Población, parentesco y red social en la frontera. Lobos (provincia de Buenos Aires) en el siglo XIX (Mar del Plata: Universidad Nacional de Mar del Plata, 2001).

Mayo, Carlos, "Patricio Belén: nada menos que un capataz", Hispanic American Historical Review 77, no. 4 (1997): 597-617.

Mayo, Carlos, Estancia y sociedad en la Pampa (1740-1820) (Buenos Aires: Biblos, 2010).

Míguez, Eduardo, "Del feudalismo al capitalismo agrario: ¿el fin de la historia ... agraria?" Boletín del Instituto de Historia Argentina y Americana "Dr. Emilio Ravignani" 46 (2017): 180-204.

Munilla, Lía, Celebrar y Gobernar. Un estudio de las fiestas cívicas en Buenos Aires, 18101835 (Buenos Aires: Miño Dávila Editores, 2013).

Myers, Jorge, "Una cuestión de identidades: La búsqueda de los orígenes de la Nación Argentina y sus aporías", Prismas 3 (1999): 275-284.

Pérez, Mariana, “¡Viva España y mueran los patricios! La conspiración de Álzaga de 1812", Americanía, no. 3 (2013): 21-55.

Perri, Gladys, "Los esclavos frente a la justicia. Resistencia y adaptación en Buenos Aires, 1780-1830", in La ley es tela de araña. Ley, justicia y sociedad rural en Buenos Aires, 178o-183o, ed. Raúl Fradkin (Buenos Aires: Prometeo libros, 2009), 51-82.

Portillo Valdés, José María, Crisis Atlántica. Autonomía e independencia en la crisis de la monarquía hispana (Madrid: Marcial Pons Ediciones de Historia, 2006).

Puiggrós, Rodolfo, De la colonia a la revolución (Buenos Aires: Retórica, 1940).

Rosal, Miguel Ángel, Africanos y afrodescendientes en el Río de la Plata. Siglos XVII-XIX (Buenos Aires: Dunken, 2009). 
Rosas, Juan Manuel de, Instrucciones a los mayordomos de estancias (Buenos Aires: Claridad, 2010).

Sabato, Hilda, Capitalismo y ganadería en Buenos Aires: la fiebre del lanar (Buenos Aires: Editorial Sudamericana, 1989).

Sala de Touron, Lucía, Nelson de la Torre, and Julio Rodríguez, Estructura económicosocial de la colonia (Montevideo: Ediciones Pueblos Unidos, 1967).

Salvatore, Ricardo, "Reclutamiento militar, disciplinamiento y proletarización en la era de Rosas", Boletín del Instituto de Historia Argentina y Americana "Dr. Emilio Ravignnani" 5 (1992): 25-47.

Sarreal, Julia, The Guarani and Their Missions: A Socioeconomic History (Stanford: Stanford University Press, 2014).

Sempat Assadourian, Carlos, et al., Modos de producción en América Latina (México: Pasado y Presente, 1973).

Sempat Assadourian, Carlos, "El sector exportador de una economía regional del interior argentino. Córdoba, 1800 - 186o”, in El sistema de la economía colonial, ed. Carlos Sempat Assadourian (México: Editorial Nueva Imagen, 1983), 18-55.

Sica, Gabriela, "Las sociedades indígenas del Tucumán colonial: una breve historia en larga duración. Siglos XVI a XIX", in La historia nacional en perspectiva regional. Nuevas investigaciones para viejos problemas, ed. Susana Bandieri and Sandra Fernández (Buenos Aires: Teseo, 2017), 41-82.

Stern, Steve, "Feudalism, Capitalism, and the World-System in the Perspective of Latin America and the Caribbean", AHR 93, no. 4 (1988): 829-872.

Socolow, Susan, Merchants of Buenos Aires 1778-1810: Family and Commerce (Cambridge: Cambridge University Press, 1978).

Tandeter, Enrique, Coacción y mercado. La minería de la plata en el Potosí Colonial, 1692-1826 (Buenos Aires: Siglo Xxi Editores, 1992).

Ternavasio, Marcela, La revolución del voto. Política y elecciones en Buenos Aires, 18101852 (Buenos Aires: Siglo XXI, 2001).

Tio Vallejo, Gabriela, "Rupturas precoces y legalidades provisorias: el fin del poder español en el Río de la Plata”, Ayer 74 (2009): 133-162. 